Check for updates

Cite this: RSC Adv., 2017, 7, 38557

Received 1st July 2017

Accepted 25th July 2017

DOI: 10.1039/c7ra07275a

rsc.li/rsc-advances

\title{
Cimifrigines $A-G$, cytotoxic triterpenes with an oxime group from the flowers of Cimicifuga frigida†
}

\begin{abstract}
Yin Nian, Hui Yan, Xiao-Nian Li, Lin Zhou and Ming-Hua Qiu*
Seven new dahurinol-type triterpene derivatives, including three aglycones, cimifrigines A-C (1-3), and four glycosides, cimifrigines D-G (4-7), were purified from the flowers of Cimicifuga frigida. These triterpenoids are characterized by an oxime group at C-15. Spectroscopic analyses and X-ray crystallography were used to determine the new structures. In the in vitro cytotoxicity screening, glycosides (4-7) exhibited more noticeable activities than the aglycones (1-3) against human HL-60, SMMC-7721, A549, MCF-7, and SW480 cell lines. Interestingly, compounds 5 and 7, bearing a $2^{\prime}-O$-acetyl moiety on the sugar unit, showed comparable cytotoxicities to the positive control, cisplatin ( $\mathrm{IC}_{50}$ : 0.5 to $\left.5.4 \mu \mathrm{M}\right)$. Whereas, analogues 4 and 6 , without the 2'-O-acetyl group, indicated weaker activities with $\mathrm{IC}_{50}$ values ranging from 8.9 to $14.3 \mu \mathrm{M}$.
\end{abstract}

\section{Introduction}

Plants of the Cimicifuga genus (Ranunculaceae) are timehonored herbal medicines worldwide. ${ }^{1-3}$ C. racemosa, namely black cohosh, is a popular food supplement in Europe and the United States for relief of menopausal disorders. ${ }^{4,5}$ In East Asia, several Cimicifuga spp., for instance, C. foetida, C. dahurica, C. heracleifolia, $C$. simplex, and $C$. japonica, have been used to alleviate fever, pain, and inflammation since ancient times, ${ }^{6,7}$

Extensive efforts have been attracted to investigate chemical constituents of this genus. 9,19-Cycloartane triterpenoids (CTs) is the major chemical component of Cimicifuga spp. and more than $300 \mathrm{CTs}^{2,3,7-27}$ have been reported (among them, our research group reported over 100 ones $^{2,3,8-24}$ ). Pharmaceutical studies revealed these CTs possessed various bioactivities, for instance, antiosteoporotic, ${ }^{28}$ cytotoxicity, ${ }^{2,14}$ anti-AIDS, ${ }^{29}$ antiAlzheimer, ${ }^{30}$ and immunosuppression. ${ }^{31}$ Nevertheless, aforementioned CTs were mainly from the rhizomes or roots of $C$. racemosa, C. foetida, C. dahurica, C. heracleifolia, and $C$. simplex. ${ }^{7-27}$ Therefore, we carried out successive investigations on the roots, aerial parts, and fruits of C. yunnanensis, an indigenous species in southwest China. ${ }^{2,3,15}$ Consequently, a number of bioactive CTs were discovered. Among them, cimyunnin A, with an unprecedented carbon skeleton from the

State Key Laboratory of Phytochemistry and Plant Resources in West China, Kunming Institute of Botany, Chinese Academy of Sciences, Kunming 650201, People's Republic of China.E-mail: mhchiu@mail.kib.ac.cn

$\dagger$ Electronic supplementary information (ESI) available: 1D and 2D NMR spectra, HRESIMS spectra of new compounds 1-7, and X-ray crystallographic data of 1 . CCDC 1545247. For ESI and crystallographic data in CIF or other electronic format see DOI: $10.1039 / \mathrm{c} 7 \mathrm{ra} 07275 \mathrm{a}$ fruits of this plant, was considered as an anti-angiogenic leading structure. It showed comparable in vitro and ex vivo activities to those of a first-line clinical medicine, sunitinib. ${ }^{3}$ Therefore, aforementioned studies exemplified that expansion of research objects in genus Cimicifuga may led to discovery of novel active CTs.

The taxonomic treatment of the Sino-Himalayan species $C$. frigida has a very long and controversial history. ${ }^{32,33}$ However, recent cytological evidence showed that this plant is the only tetraploid $(2 n=32)$ currently known in the genus, which together with morphological features confirmed its independent species status. ${ }^{34}$ Thus, it is of interest to explore whether there are novel bioactive compounds in this plant. In the present study, we initially carried out a study on the flowers of $C$. frigida from Litang County, Sichuan Province. Consequently, seven new 9,19-cycloartane triterpene derivatives (Fig. 1), cimifrigines A-G (1-7), were isolated. Their structures were elucidated by the help of MS, NMR, and single-crystal X-ray diffraction techniques. The unique characteristic of these analogues is that containing an oxime group at C-15 based on the dahurinol-skeleton. In addition, the isolated compounds showed potent to week cytotoxicities against human HL-60, SMMC-7721, A549, MCF-7, and SW-480 cell lines.

\section{Results and discussion}

Cimifrigine A (1), purified as colorless crystals. The HREIMS ion peak at $m / z$ 559.3864 $[\mathrm{M}]^{+}$(calcd 559.3873) determined its molecular formula as $\mathrm{C}_{33} \mathrm{H}_{53} \mathrm{NO}_{6}$, requiring 8 double-bond equivalents. The ${ }^{1} \mathrm{H}$ NMR spectrum (Table 1 ) showed characteristic cyclopropane methylene signals at $\delta_{\mathrm{H}} 0.29$ and 0.52 (each $1 \mathrm{H}$, brs), a secondary methyl signal at $\delta_{\mathrm{H}} 0.88(\mathrm{~d}, J=5.9$ 


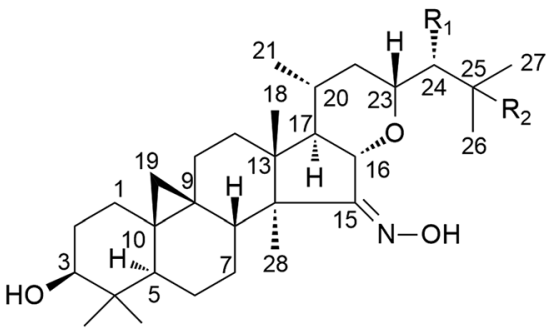

$$
\begin{aligned}
& 1 R_{1}=-O \text {-acetyl, } R_{2}=-O C H_{3} \\
& 2 R_{1}=-O \text {-acetyl, } R_{2}=-O H \\
& 3 R_{1}=-O H, R_{2}=-O_{3} H_{3}
\end{aligned}
$$

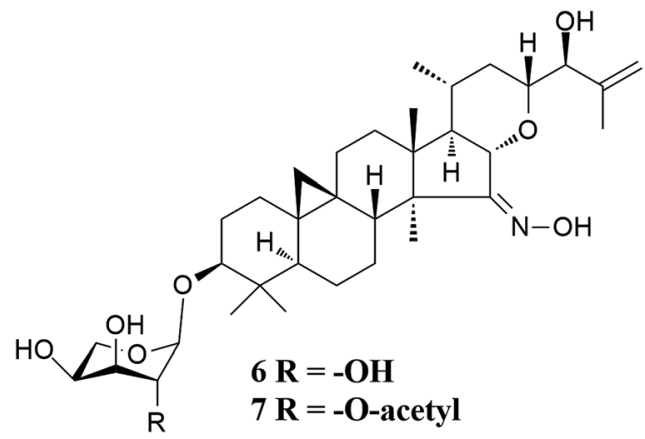

Fig. 1 Structures of compounds 1-7.

$\mathrm{Hz}$ ), five tertiary methyl groups at $\delta_{\mathrm{H}} 1.04-1.59$, and an active hydrogen signal at $\delta_{\mathrm{H}} 12.32$, respectively. In the ${ }^{13} \mathrm{C}$ NMR spectrum (Table 2), an olefinic (or a carbonyl) carbon signal at $\delta_{\mathrm{C}} 164.34$ (C-15), and five oxygenated carbons at $\delta_{\mathrm{C}} 78.01$ (C-3, d), 80.55 (C-16, d), 78.76 (C-23, d), 77.13 (C-24, d), and 77.53 $(\mathrm{C}-25, \mathrm{~s})$ were also observed. Aforementioned data suggested that 1 was a highly oxygen-bearing 9,19-cycloartane triterpenoid with a six-ring carbon skeleton.

Study of the ${ }^{1} \mathrm{H}^{1}{ }^{1} \mathrm{H}$ COSY (Fig. 2) spectrum of 1 revealed the existence of partial structures $\mathrm{C} 1 / \mathrm{C}-2 / \mathrm{C} 3\left(-\mathrm{CH}_{2}-\mathrm{CH}_{2}-\mathrm{CH}-\right), \mathrm{C}-5 /$ C-6/C-7/C $8\left(-\mathrm{CHCH}_{2} \mathrm{CH}_{2} \mathrm{CH}-\right)$, C-11/C-12 $\left(-\mathrm{CH}_{2} \mathrm{CH}_{2}-\right)$, and C$16 / \mathrm{C}-17 / \mathrm{C}-20(\mathrm{C}-21) / \mathrm{C}-22 / \mathrm{C}-23 \quad\left(-\mathrm{CHCHCH}-\left(\mathrm{CH}_{3}\right) \mathrm{CH}_{2} \mathrm{CH}-\right)$, which consistent with typical rings A-E of a dahurinol-type triterpene. ${ }^{11,13,35,36}$ Based on HMBC correlation from $\mathrm{H}-16$ at $\delta_{\mathrm{H}}$ 4.24 to the oxygenated methine at $\delta_{\mathrm{C}} 78.76$ (C-23), and the existence of the spin system C-16/C-17/C-20(C-21)/C-22/C-23, the ring $\mathrm{E}$ was established as shown. ${ }^{1} \mathrm{H}^{-}{ }^{1} \mathrm{H}$ COSY association between $\mathrm{H}-23\left(\delta_{\mathrm{H}} 4.11\right)$ and $\mathrm{H}-24\left(\delta_{\mathrm{H}} 5.34\right)$ indicated the linkage of C-23 and C-24. In addition, the connection of C-24 and C-25 was elucidated from the HMBC correlation of $\mathrm{H}-24\left(\delta_{\mathrm{H}} 5.34\right)$ to quaternary carbon resonance at $\delta_{\mathrm{C}} 77.53$ (C-25). Similarly, an acetoxy group was attached to $\mathrm{C}-24$, and $\mathrm{CH}_{3}-26\left(\delta_{\mathrm{H}} 1.59\right)$ and $\mathrm{CH}_{3}-27\left(\delta_{\mathrm{H}} 1.56\right)$, and the methoxy group at $\delta_{\mathrm{H}} 3.24$ were linked to C-25 based on the HMBC correlations (Fig. 2). Thus, the side chain of 1 was constructed. Further analyses of HMBC crosspeaks from $\mathrm{H}-16\left(\delta_{\mathrm{H}} 4.24\right)$ to $\mathrm{C}-14\left(\delta_{\mathrm{C}} 51.67\right)$, and the olefinic (or carbonyl) carbon signal $(\mathrm{C}-15)$ at $\delta_{\mathrm{C}} 164.34 ; \mathrm{H}-17\left(\delta_{\mathrm{H}} 1.60\right)$ to $\mathrm{C}-13\left(\delta_{\mathrm{C}} 42.50\right)$ and C-14 $\left(\delta_{\mathrm{C}} 51.67\right) ; \mathrm{CH}_{3}-18\left(\delta_{\mathrm{H}} 1.07\right)$ to C-13 $\left(\delta_{\mathrm{C}}\right.$ $42.50), \mathrm{C}-14\left(\delta_{\mathrm{C}} 51.67\right)$ and $\mathrm{C}-17\left(\delta_{\mathrm{C}} 54.60\right) ; \mathrm{CH}_{3}-28\left(\delta_{\mathrm{H}} 1.14\right)$ to C-

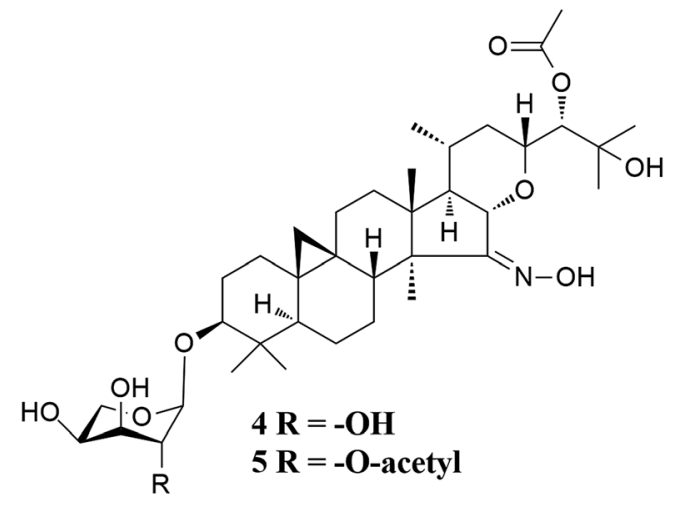

$14\left(\delta_{\mathrm{C}} 51.67\right)$ and $\mathrm{C}-15\left(\delta_{\mathrm{C}} 164.34\right)$, suggested the presence of a five-membered ring $\mathrm{D}$ with an oxime unit at C-15 (Fig. 2). In the HMBC spectrum, the active hydrogen $\left(\delta_{\mathrm{H}} 12.32\right)$ coupled with C-15 $\left(\delta_{\mathrm{C}} 164.34\right)$ further supported this elucidation. Thus, the planar structure of 1 was established as shown (Fig. 2).

The orientations of core structure of $\mathbf{1}$ was established by the ROESY correlations (Fig. 2) between H-5 (biogenetically $\alpha$ oriented) and $\mathrm{H}-3$, Me-28 (biogenetically $\alpha$-oriented) and $\mathrm{H}-17$, Me-18 (biogenetically $\beta$-oriented) and $\mathrm{H}-16, \mathrm{Me}-18$ and $\mathrm{H}-20$, and $\mathrm{H}-23$ and $\mathrm{H}-16$. In addition, due to its similar coupling constant of $\mathrm{H}-24$ (brs) as that of isodahurinyl-type molecules $(<2$ $\mathrm{Hz}$ ), the configuration of $\mathrm{C}-24$ of $\mathbf{1}$ was deduced as $S$ (the coupling constants of $\mathrm{H}-24$ of dahurinyl-type compounds is around 6-9 Hz). ${ }^{11,13,35,36}$ Finally, X-ray diffraction analysis (Fig. 3) allowed to confirm the oxime group at $\mathrm{C}-15$, the relative configurations, and the stereochemistry of $S$ at C-24 of 1 due to the Hooft parameter 0.13(8) for 1536 Bijvoet pairs. ${ }^{37}$ Therefore, the structure of 1 was constructed as shown.

The molecular formulas of cimifrigines B (2) and C (3) were determined as $\mathrm{C}_{33} \mathrm{H}_{53} \mathrm{NO}_{6}$ and $\mathrm{C}_{31} \mathrm{H}_{51} \mathrm{NO}_{5}$ by the HREIMS ([M] $\mathrm{m} / \mathrm{z}$ 545.3723, calcd 545.3716, and $[\mathrm{M}]^{+} \mathrm{m} / \mathrm{z}$ 517.3776, calcd 517.3767 , respectively). The NMR spectra (Tables 1 and 2) of 2 and 3 resembled to those of $\mathbf{1}$. The main differences were the substituent groups at C-25 and C-24, respectively. For compound 2, the methoxy group was replaced by a hydroxyl group at C-25. This elucidation was supported by 14 Da less of the molecular weight of 2 , and the upfield shift of C-25 by $4.42 \mathrm{ppm}$. Therefore, a hydroxy group instead of an acetoxy unit at C-24 in compound 3 was determined by similar analyses. ROESY associations of $\mathrm{H}-3$ / 
Table $1{ }^{1} \mathrm{H}$ NMR data of compounds $1-7$ in pyridine $-d_{5}$ at $500 \mathrm{MHz}(\delta$ in ppm, $J \mathrm{in} \mathrm{Hz}$ )

\begin{tabular}{|c|c|c|c|c|c|c|c|}
\hline Position & 1 & 2 & 3 & 4 & 5 & 6 & 7 \\
\hline \multirow[t]{2}{*}{1} & $1.52^{a}$ & $1.57 \mathrm{~m}$ & $1.55 \mathrm{~m}$ & $1.54 \mathrm{~m}$ & $1.52 \mathrm{~m}$ & $1.58 \mathrm{~m}$ & $1.51 \mathrm{~m}$ \\
\hline & $1.12^{a}$ & $1.21^{a}$ & $1.18^{a}$ & $1.18 \mathrm{~m}$ & $1.15^{a}$ & $1.23 \mathrm{~m}$ & $1.16 \mathrm{~m}$ \\
\hline \multirow[t]{2}{*}{2} & $1.96 \mathrm{~m}$ & $2.02 \mathrm{~m}$ & $1.97 \mathrm{~m}$ & $2.36 \mathrm{~m}$ & $2.29 \mathrm{~m}$ & $2.42 \mathrm{~m}$ & $2.27 \mathrm{~m}$ \\
\hline & $1.82 \mathrm{~m}$ & $1.91 \mathrm{~m}$ & $1.89 \mathrm{~m}$ & $1.94 \mathrm{~m}$ & $1.87 \mathrm{~m}$ & $1.99 \mathrm{~m}$ & $1.87 \mathrm{~m}$ \\
\hline 3 & $3.51 \mathrm{~m}$ & 3.57 dd $(11.2,3.4)$ & $3.54 \mathrm{~m}$ & 3.49 dd $(11.6,4.2)$ & 3.39 dd $(11.6,4.4)$ & 3.54 dd $(11.6,4.3)$ & $3.37 \mathrm{dd}(11.2,3.8)$ \\
\hline \multicolumn{8}{|c|}{${ }^{2}$} \\
\hline 5 & $1.27 \mathrm{~m}$ & $1.31 \mathrm{dd}(12.4,4.1)$ & $1.32 \mathrm{dd}(12.5,4.3)$ & $1.30 \mathrm{dd}(12.6,4.3)$ & $1.30 \mathrm{dd}(12.4,4.1)$ & $1.37 \mathrm{dd}(12.5,4.2)$ & $1.31 \mathrm{~m}$ \\
\hline \multirow[t]{2}{*}{6} & $1.52^{a}$ & $1.56 \mathrm{~m}$ & $1.59^{a}$ & $1.50 \mathrm{~m}$ & $1.51 \mathrm{~m}$ & $1.59 \mathrm{~m}$ & $1.55 \mathrm{~m}$ \\
\hline & $0.71 \mathrm{~m}$ & $0.73 \mathrm{q}(12.7)$ & $0.76 \mathrm{~m}$ & $0.65 \mathrm{q}(12.4)$ & $0.68 \mathrm{q}(12.7)$ & $0.75 \mathrm{q}(12.5)$ & $0.73 \mathrm{~m}$ \\
\hline \multirow[t]{2}{*}{7} & $2.54 \mathrm{~m}$ & $2.57 \mathrm{~m}$ & $2.60 \mathrm{~m}$ & $2.53 \mathrm{~m}$ & $2.55 \mathrm{~m}$ & $2.60 \mathrm{~m}$ & $2.59 \mathrm{~m}$ \\
\hline & $1.01^{a}$ & $1.07^{a}$ & $1.08^{a}$ & $1.10^{a}$ & $1.02 \mathrm{~m}$ & $1.13 \mathrm{~m}$ & $1.08^{a}$ \\
\hline 8 & $1.82 \mathrm{~m}$ & $1.84 \mathrm{~m}$ & $1.86 \mathrm{~m}$ & $1.80 \mathrm{~m}$ & $1.80 \mathrm{~m}$ & $1.87 \mathrm{dd}(12.6,3.5)$ & $1.84 \mathrm{~m}$ \\
\hline \multicolumn{8}{|l|}{9} \\
\hline \multicolumn{8}{|l|}{10} \\
\hline \multirow[t]{2}{*}{11} & $1.99 \mathrm{~m}$ & $2.04 \mathrm{~m}$ & $2.03 \mathrm{~m}$ & $1.98 \mathrm{~m}$ & $1.97 \mathrm{~m}$ & $2.05^{a}$ & $2.00^{a}$ \\
\hline & $1.03^{a}$ & $1.07^{a}$ & $1.06^{a}$ & $1.10^{a}$ & $0.99 \mathrm{~m}$ & $1.05^{a}$ & $1.00 \mathrm{~m}$ \\
\hline 12 & $1.52^{a}(2 \mathrm{H})$ & $1.58 \mathrm{~m}(2 \mathrm{H})$ & $1.55 \mathrm{~m}(2 \mathrm{H})$ & $1.55 \mathrm{~m}(2 \mathrm{H})$ & $1.54 \mathrm{~m}(2 \mathrm{H})$ & $1.62 \mathrm{~m}(2 \mathrm{H})$ & $1.58 \mathrm{~m}(2 \mathrm{H})$ \\
\hline \multicolumn{8}{|l|}{13} \\
\hline \multicolumn{8}{|l|}{14} \\
\hline \multicolumn{8}{|l|}{15} \\
\hline 16 & $4.24 \mathrm{~d}(10.1)$ & 4.41 brd (10.3) & $4.37 \mathrm{~d}(10.2)$ & 4.23 brd (10.4) & $4.27 \mathrm{~d}(10.4)$ & 4.40 brd (10.1) & $4.38 \mathrm{~d}(9.9)$ \\
\hline 17 & $1.60^{a}$ & 1.66 brd (11.0) & $1.58^{a}$ & $1.62 \mathrm{~m}$ & $1.63 \mathrm{~m}$ & $1.65 \mathrm{~m}$ & $1.62 \mathrm{~m}$ \\
\hline 18 & $1.07 \mathrm{~s}$ & $1.14 \mathrm{~s}$ & $1.09 \mathrm{~s}$ & $1.07 \mathrm{~s}$ & $1.09 \mathrm{~s}$ & $1.09 \mathrm{~s}$ & $1.08 \mathrm{~s}$ \\
\hline \multirow[t]{2}{*}{19} & $0.52 \mathrm{brs}$ & $0.56 \mathrm{~d}(3.3)$ & $0.55 \mathrm{~d}(3.7)$ & $0.48 \mathrm{~d}(3.3)$ & $0.45 \mathrm{~d}(3.5)$ & $0.53 \mathrm{~d}(3.4)$ & $0.47 \mathrm{~d}(3.3)$ \\
\hline & $0.29 \mathrm{brs}$ & $0.34 \mathrm{~d}(3.8)$ & $0.32 \mathrm{~d}(4.0)$ & $0.26 \mathrm{~d}(3.9)$ & $0.23 \mathrm{~d}(3.9)$ & $0.30 \mathrm{~d}(3.9)$ & $0.24 \mathrm{~d}(3.8)$ \\
\hline 20 & $1.77 \mathrm{~m}$ & $1.84 \mathrm{~m}$ & $1.80 \mathrm{~m}$ & $1.80 \mathrm{~m}$ & $1.80 \mathrm{~m}$ & $1.76 \mathrm{~m}$ & $1.75 \mathrm{~m}$ \\
\hline 21 & $0.88 \mathrm{~d}(5.9)$ & $0.93 \mathrm{~d}(6.3)$ & $0.91 \mathrm{~d}(6.1)$ & $0.89 \mathrm{~d}(6.3)$ & $0.90 \mathrm{~d}(6.3)$ & $0.93 \mathrm{~d}(6.3)$ & $0.92 \mathrm{~d}(6.3)$ \\
\hline \multirow[t]{2}{*}{22} & $1.65 \mathrm{~m}$ & 1.66 brd (11.0) & $1.84 \mathrm{~m}$ & $1.65 \mathrm{~m}$ & $1.68 \mathrm{~m}$ & $1.68 \mathrm{~m}$ & $1.65 \mathrm{~m}$ \\
\hline & $1.42 \mathrm{~m}$ & $1.50^{a}$ & $1.62^{a}$ & $1.41 \mathrm{~m}$ & $1.44 \mathrm{~m}$ & $1.32^{a}$ & $1.28^{a}$ \\
\hline 23 & $4.11 \mathrm{~d}(11.1)$ & 4.39 brd (10.1) & 4.25 brd (11.3) & 4.23 brd (10.4) & $4.26 \mathrm{~m}$ & $4.02 \mathrm{~m}$ & $3.99 \mathrm{~m}$ \\
\hline 24 & $5.34 \mathrm{brs}$ & $5.26 \mathrm{brs}$ & $3.64 \mathrm{~s}$ & $5.55 \mathrm{brs}$ & $5.59 \mathrm{~s}$ & $4.37 \mathrm{~d}(6.3)$ & $4.34 \mathrm{~d}(6.3)$ \\
\hline \multicolumn{8}{|l|}{25} \\
\hline \multirow[t]{2}{*}{26} & $1.59 \mathrm{~s}$ & $1.68 \mathrm{~s}$ & $1.57 \mathrm{~s}$ & $2.02 \mathrm{~s}$ & $2.05 \mathrm{~s}$ & $5.30 \mathrm{~s}$ & $5.27 \mathrm{~s}$ \\
\hline & & & & & & $5.04 \mathrm{~s}$ & $5.01 \mathrm{~s}$ \\
\hline 27 & $1.56 \mathrm{~s}$ & $1.50 \mathrm{~s}$ & $1.61 \mathrm{~s}$ & $2.09 \mathrm{~s}$ & $2.13 \mathrm{~s}$ & $2.05 \mathrm{~s}$ & $2.02 \mathrm{~s}$ \\
\hline 28 & $1.14 \mathrm{~s}$ & $1.19 \mathrm{~s}$ & $1.16 \mathrm{~s}$ & $1.14 \mathrm{~s}$ & $1.15 \mathrm{~s}$ & $1.29 \mathrm{~s}$ & $1.27 \mathrm{~s}$ \\
\hline 29 & $1.04 \mathrm{~s}$ & $1.09 \mathrm{~s}$ & $1.08 \mathrm{~s}$ & $1.00 \mathrm{~s}$ & $0.96 \mathrm{~s}$ & $1.05 \mathrm{~s}$ & $0.96 \mathrm{~s}$ \\
\hline 30 & $1.16 \mathrm{~s}$ & $1.21 \mathrm{~s}$ & $1.20 \mathrm{~s}$ & $1.27 \mathrm{~s}$ & $1.09 \mathrm{~s}$ & $1.32 \mathrm{~s}$ & $1.08 \mathrm{~s}$ \\
\hline \multicolumn{8}{|l|}{ 3-Ara } \\
\hline $1^{\prime}$ & & & & $4.79 \mathrm{~d}(7.1)$ & $4.75 \mathrm{~d}(7.7)$ & $4.83 \mathrm{~d}(7.1)$ & $4.74 \mathrm{~d}(7.5)$ \\
\hline $2^{\prime}$ & & & & $4.45 \mathrm{t}(7.5)$ & 5.95 dd $(9.5,7.8)$ & $4.50 \mathrm{t}(7.9)$ & $5.92 \mathrm{t}(8.1)$ \\
\hline $3^{\prime}$ & & & & $4.16 \mathrm{dd}(8.8,3.2)$ & $4.21 \mathrm{~m}$ & $4.20 \mathrm{dd}(8.8,3.0)$ & 4.19 dd $(9.6,3.0)$ \\
\hline $4^{\prime}$ & & & & $4.32 \mathrm{brs}$ & $4.30 \mathrm{brs}$ & $4.35 \mathrm{brs}$ & $4.29 \mathrm{brs}$ \\
\hline \multirow[t]{2}{*}{$5^{\prime}$} & & & & $4.29 \mathrm{~m}$ & 4.29 brd (11.4) & $4.34 \mathrm{~m}$ & $4.28 \mathrm{~m}$ \\
\hline & & & & $3.78 \mathrm{~d}(11.4)$ & $3.77 \mathrm{~d}(11.3)$ & $3.83 \mathrm{~d}(10.9)$ & $3.77 \mathrm{~d}(11.3)$ \\
\hline $24-\mathrm{OCOCH}_{3}$ & $2.16 \mathrm{~s}$ & $2.23 \mathrm{~s}$ & & $2.22 \mathrm{~s}$ & $2.13 \mathrm{~s}$ & & \\
\hline $25-\mathrm{OCH}_{3}$ & $3.24 \mathrm{~s}$ & & $3.29 \mathrm{~s}$ & & & & \\
\hline $2^{\prime}-\mathrm{OCOC} \underline{\mathrm{H}}_{3}$ & & & & & $2.24 \mathrm{~s}$ & & $2.11 \mathrm{~s}$ \\
\hline $\mathrm{C}=\mathrm{N}-\mathrm{OH}$ & $12.32 \mathrm{~s}$ & $12.73 \mathrm{~s}$ & $12.31 \mathrm{~s}$ & $12.43 \mathrm{~s}$ & $12.43 \mathrm{~s}$ & $12.56 \mathrm{~s}$ & \\
\hline
\end{tabular}

$\mathrm{H} 5, \mathrm{H}-16 / \mathrm{CH}_{3}-18, \mathrm{H}-20 / \mathrm{CH}_{3}-18$ and $\mathrm{H}-16 / \mathrm{H}-23$ both in 2 and 3 suggested the $\alpha, \beta, \beta$, and $\beta$ orientations of $\mathrm{H}-3, \mathrm{H}-16, \mathrm{H}-20$, and $\mathrm{H}-$ 23, respectively. The $S$ configuration of C-24 of 2 and 3 was proposed by the same way as that of $\mathbf{1}$. Accordingly, the structures of 2 and 3 were established as shown.

Cimifrigine D (4) had the molecular formula $\mathrm{C}_{37} \mathrm{H}_{59} \mathrm{NO}_{10}$ as determined by HREIMS ( $\mathrm{m} / z$ 677.4129 $[\mathrm{M}]^{+}$, calcd 677.4139). In the ${ }^{1} \mathrm{H}$ NMR spectrum, resonances for an anomeric proton at $\delta_{\mathrm{H}}$ $4.79\left(\mathrm{H}-1^{\prime}, 1 \mathrm{H}, \mathrm{d}, J=7.1 \mathrm{~Hz}\right)$, and a cyclopropane methylene at
$\delta_{\mathrm{H}} 0.20(6 \mathrm{H}, \mathrm{d}, J=3.9 \mathrm{~Hz})$ and $0.48(1 \mathrm{H}, \mathrm{d}, J=3.3 \mathrm{~Hz})$ were observed. These data indicated 4 was a 9,19-cycloartane triterpene substituted with a sugar unit. Analyses of NMR spectroscopic data revealed that, structurally, the aglycone part of 4 was identical to 2 . The sugar unit in $\mathbf{4}$ was located to $\mathrm{C}-3$ on the basis of $\mathrm{HMBC}$ correlation between the anomeric proton at $\delta_{\mathrm{H}} 4.79 \mathrm{~J}=$ $7.1 \mathrm{~Hz}$ ) and the methine signal at $\delta_{\mathrm{C}} 88.59$ (C-3). In addition, by comparing its TLC and specific rotation with a standard after acid hydrolysis, the sugar was determined as L-arabinose. ROESY 
Table $2{ }^{13} \mathrm{C}$ NMR data of compounds $1-7$ in pyridine- $d_{5}$ at $150 \mathrm{MHz}(\delta$ in ppm)

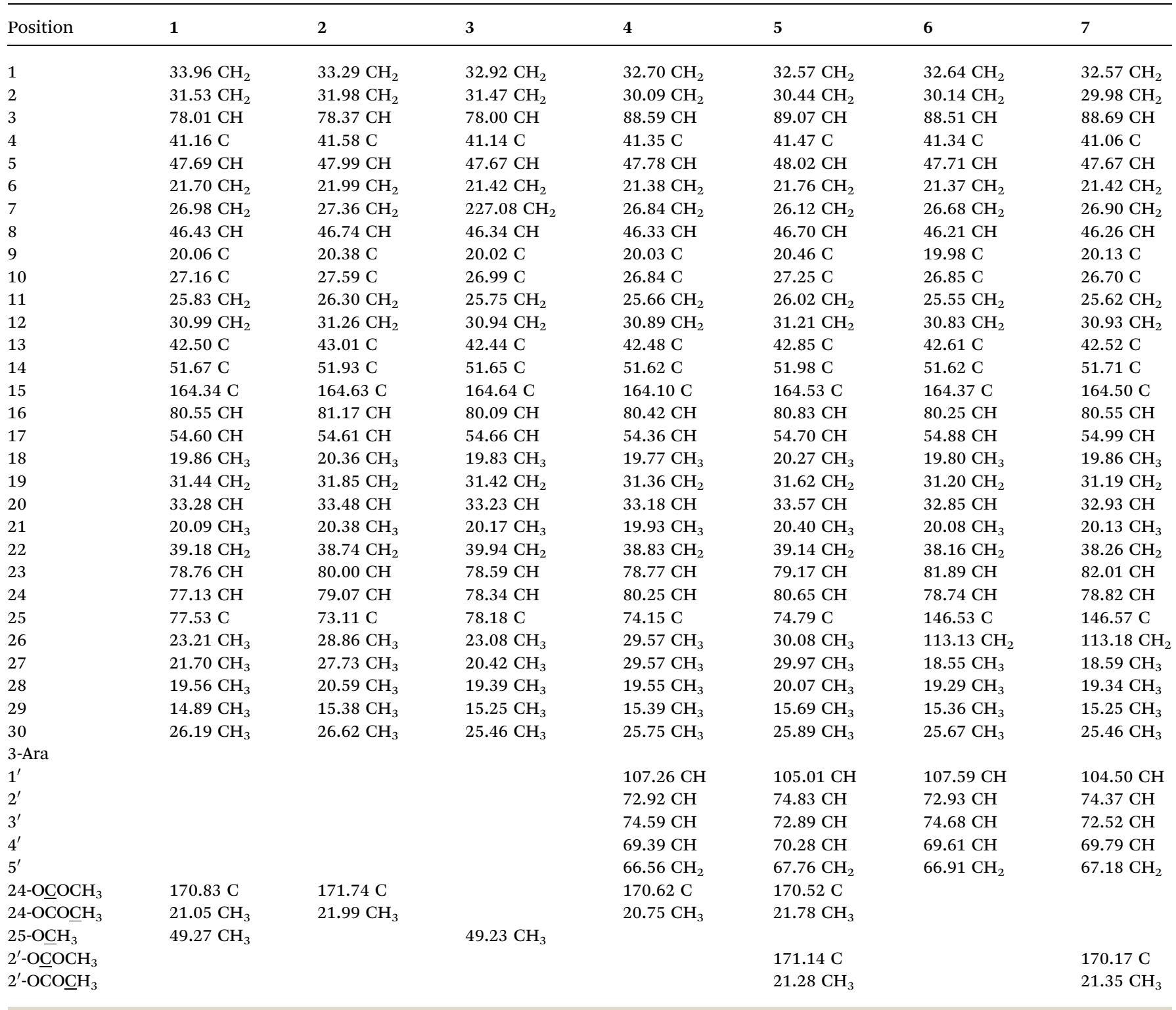

correlations of $\mathrm{H}-16 / \mathrm{CH}_{3}-18, \mathrm{H}-20 / \mathrm{CH}_{3}-18$ and $\mathrm{H}-16 / \mathrm{H}-23$ sug- $\quad$ was established by the cross-peak of $\mathrm{H}-3 / \mathrm{H}-5$. The configuration gested an $\alpha$-orientation of the substituents at C-16, C-20 and C-23, respectively. Whereas, a $\beta$-orientation of the substituent at $\mathrm{C}-3$ of C-24 was proposed as $S$ by the same way as that of 1 . Therefore, the structure of $\mathbf{4}$ was elucidated as shown.
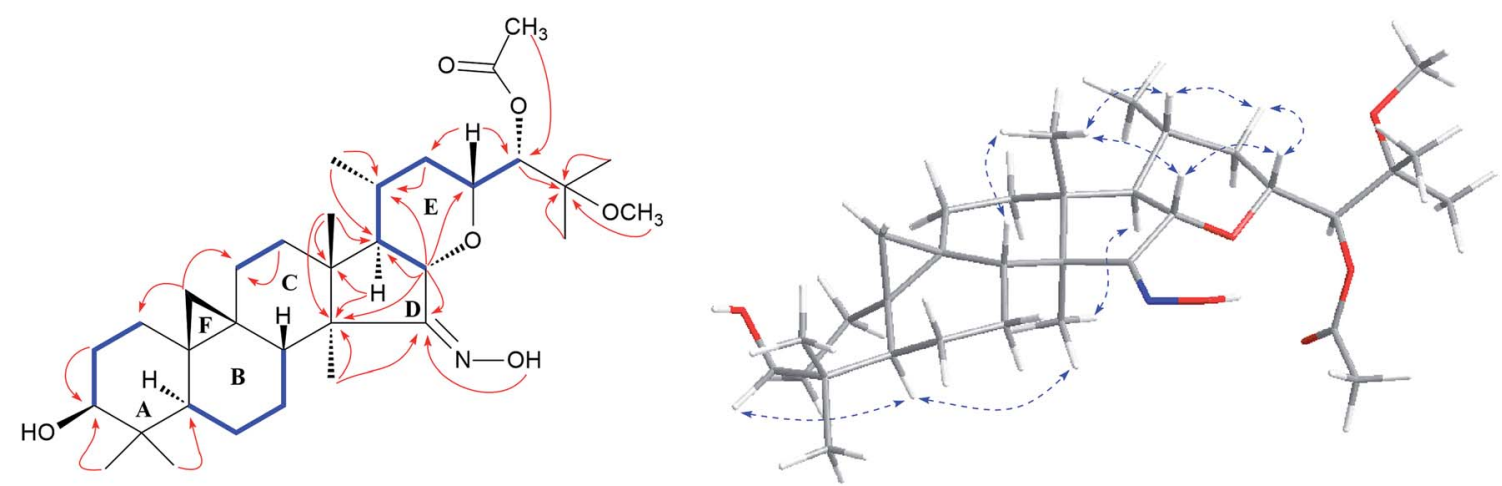

Fig. 2 Major $\mathrm{HMBC}(\longrightarrow),{ }^{1} \mathrm{H}-{ }^{1} \mathrm{H}$ COSY $(\longrightarrow)$, and ROESY $(\longrightarrow---\rightarrow)$ correlations of compound 1. 


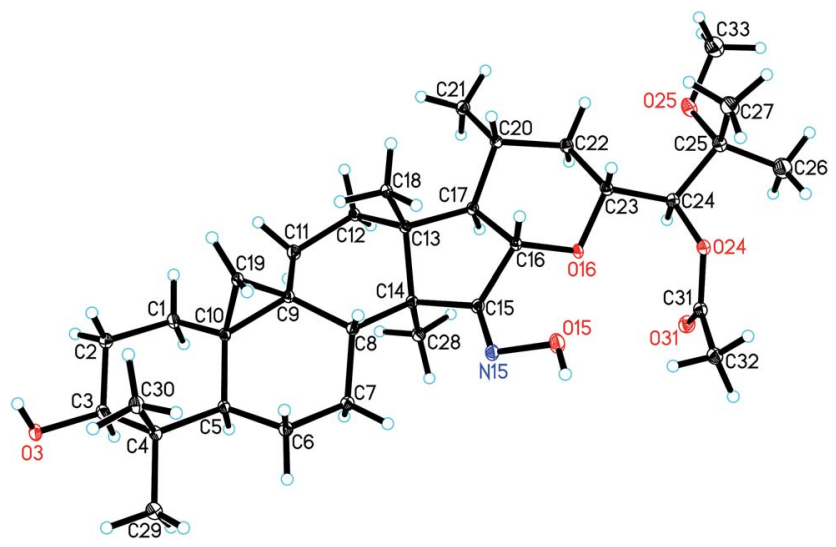

Fig. 3 X-ray crystal structure of 1.

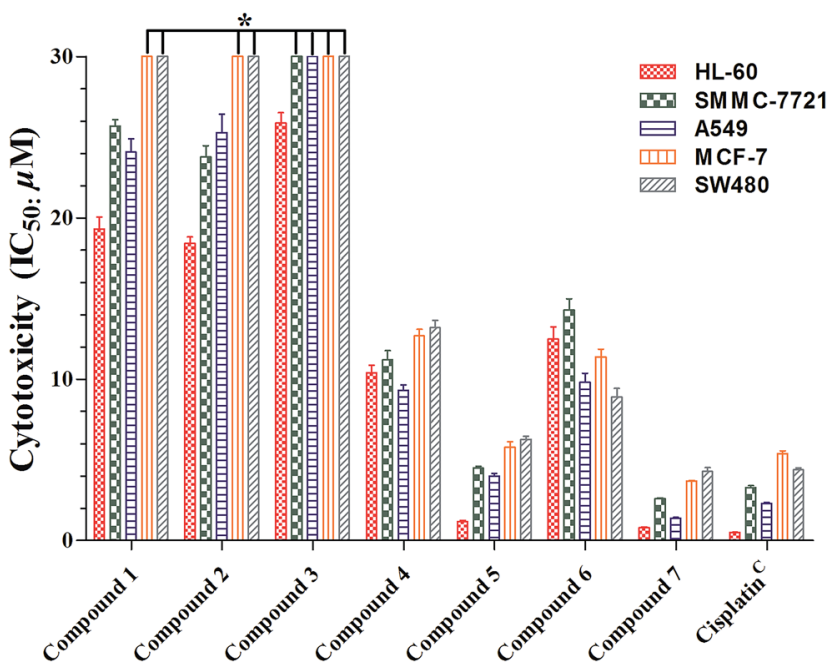

Fig. 4 Cytotoxicity of compounds isolated from the flowers of $C$. frigida. Results are expressed as the average $(n=3)$ of $I C_{50}$ values $(\mu M)$. $0.1 \%$ DMSO as the solvent control and did not show any cytotoxicity to those cell lines. 'Used as a positive control substance for the cytotoxicity assay. ${ }^{*}$ The $I C_{50}$ values are $>30 \mu \mathrm{M}$.

On the basis of the HREIMS peak at $m / z 719.4281[\mathrm{M}]^{+}$(calcd 719.4245), the molecular formula of cimifrigine $\mathrm{E}$ (5) was determined as $\mathrm{C}_{39} \mathrm{H}_{61} \mathrm{NO}_{11}$. Comparison of NMR data of compounds 5 and $\mathbf{4}$ revealed these two compounds were structurally identical except for the sugar unit. The molecular weight difference between 5 and 4 was $42 \mathrm{Da}$, consistent with an acetyl unit. Besides, $\mathrm{H}-\mathbf{2}^{\prime}$ signal of $\mathbf{5}$ was shifted to downfield at $\delta_{\mathrm{H}} 5.95$, which together with the HMBC correlation between the acetoxy methyl group $\left(\delta_{\mathrm{H}} 2.13\right)$ and $\mathrm{C}-2^{\prime}\left(\delta_{\mathrm{C}} 74.83\right)$ located an acetoxy group at $\mathrm{C}-2^{\prime}$ of 5 . The sugar was identified as L-arabinose using the same way as that of 4 . The orientations of $\mathrm{H}-3, \mathrm{H}-$ $16, \mathrm{H}-20$, and $\mathrm{H}-23$ were determined as $\alpha, \beta, \beta$, and $\beta$, respectively, by analyses of ROESY correlations. In addition, the configuration of C-24 was elucidated as $S$ by comparison of coupling constant of $\mathrm{H}-24$ of 5 with those of known isodahurinyl-type triteroids. ${ }^{11,13,35,36}$ Thus, the structure of 5 was determined as shown.
The spectroscopic features of cimifrigines F (6) and G (7) resembled to each other except for the sugar unit. The molecular formulas of 6 and 7 were determined as $\mathrm{C}_{35} \mathrm{H}_{55} \mathrm{NO}_{8}$ and $\mathrm{C}_{37} \mathrm{H}_{57} \mathrm{NO}_{9}$, respectively, by HREIMS ([M] $]^{+} \mathrm{m} / z$ 617.3943, calcd 617.3928, and $[\mathrm{M}]^{+} \mathrm{m} / \mathrm{z}$ 659.4053, calcd 659.40337, respectively). Same to that of compounds 4 and $\mathbf{5}$, the molecular weight difference between 6 and 7 was $42 \mathrm{Da}$, which equivalent to an acetyl moiety. In addition, the acetoxy group in 7 was located to C-2' based on the HMBC correlation of the acetoxy methyl group $\left(\delta_{\mathrm{H}} 2.11\right)$ and C-2 ${ }^{\prime}\left(\delta_{\mathrm{C}} 74.37\right)$. Structurally, the aglycone part of 6 and 7 was similar to that of 2 except that a terminal double bond was formed between C-25 and C-26 in 6 and 7. HMBC correlations from the olefinic protons at $\delta_{\mathrm{H}} 5.30$ (for 6) and 5.27 (for 7 ) and $\delta_{\mathrm{H}} 5.04$ (for 6) and 5.01 (for 7) to C-24 ( $\delta_{\mathrm{C}} 78.74$ for 6 and 78.82 for 7 ), C-25 ( $\delta_{\mathrm{C}} 146.53$ for 6 and 146.57 for 7 ), and $\mathrm{CH}_{3}-27$ $\left(\delta_{\mathrm{C}} 18.55\right.$ for 6 and 18.59 for 7$)$ further supported this elucidation. The sugar obtained after acid hydrolysis was identified as L-arabinose by comparing its TLC and specific rotation with a standard. The $\alpha$-orientation of the substituents at C-16, C-20 and $\mathrm{C}-23$ were determined by ROESY correlations of $\mathrm{H}-16 /$ $\mathrm{CH}_{3}-18, \mathrm{H}-20 / \mathrm{CH}_{3}-18$ and $\mathrm{H}-16 / \mathrm{H}-23$. Whereas, correlation of $\mathrm{H}-$ $3 / \mathrm{H}-5$ indicated the $\beta$-orientation of the substituent at C-3. The coupling constant of $\mathrm{H}-24$ for 6 and 7 was $6.3 \mathrm{~Hz}$ which consistent with those of dahurinyl-type compounds (6-9 $\mathrm{Hz}){ }^{11,13,35,36}$ Thus, the stereochemistry of C-24 was elucidated as $S$ and the structure of 6 and 7 were determined as shown.

Cimifrigines A-G (1-7) were evaluated against human HL-60, SMMC-7721, A549, MCF-7, and SW-480 cell lines for their cytotoxicities. All compounds (1-7) showed different levels of activities with the glycoside derivatives (4-7) stronger than the aglycone analogues (1-3) (Fig. 4, Table S1 $\dagger$ ). Compounds 5 and 7 exhibited as potent activities as positive control cisplatin $\left(\mathrm{IC}_{50}\right.$ : 0.5 to $5.4 \mu \mathrm{M}$ ) against all cell lines with $\mathrm{IC}_{50}$ values ranging from 0.8 to $6.3 \mu \mathrm{M}$. However, 4 and 6 indicated broad spectrum and moderate activities with $\mathrm{IC}_{50}$ values around 8.9 to $14.3 \mu \mathrm{M}$. Structurally, the C-2' position was substituted by an acetoxy unit in 5 and 7. While, a hydroxy group was located at this position in 4 and 6. Therefore, based on the aforementioned data, it may gave the preliminary conclusion that sugar unit is critical to the cytotoxicities of this new type of CTs. Besides, hydrophobic groups like acetoxy at the sugar unit could enhance the activities as much as one order of magnitude.

\section{Conclusions}

As mentioned in the Introduction besides the roots of Cimicifuga spp., nontraditionally used part, such as fruits, also contained novel active CTs. Therefore, we expanded the research target to the flowers of $C$. frigida, a species of which the chemical constituents have not been reported yet. As a result, seven new dahurinol-type analogues, cimifrigines A-G (1-7), with an oxime group at C-15, were isolated and identified. Significantly, all of the compounds had cytotoxic effect and two of them showed comparable activity as that of cisplatin, the positive control, in the in vitro cytotoxicity assay. Besides, preliminary structure-activity relationship also discussed in the study which afforded potential informations for further chemical 
modifications. In summary, to the best of our knowledge, this is the first example of naturally occured oxime group bearing cytotoxic CTs. In addition, on the basis of the delightful discoveries from the fruits and flowers of Cimicifuga spp., we assume that the more sophisticated parts of this genus, such as pollen and vegetative organ, may also contain novel active chemical constituents and deserved further investigations.

\section{Experimental section}

\section{General experimental procedures}

Column chromatography (CC) was run on silica gel (200-300 mesh, Qingdao Marine Chemical, Inc.), and Lichroprep RP-18 (40-63 $\mu \mathrm{m}$, Merck). Semipreparative HPLC was carried out on an Agilent 1100 liquid chromatography system using an YMCPack $10 \mathrm{~mm} \times 250 \mathrm{~mm}$ column (Pro C18 RS). Precoated TLC plates (200-250 $\mu \mathrm{m}$ thickness, silica gel $60 \mathrm{~F}_{254}$, Qingdao Marine Chemical, Inc.) were used for thin-layer chromatography. The spots in TLC were visualized by heating after spraying with $10 \%$ aq. $\mathrm{H}_{2} \mathrm{SO}_{4} \cdot 1 \mathrm{D}$ and 2D NMR spectra were performed on Bruker DRX-500 and Avance III-600 MHz spectrometers (Bruker, Zürich, Switzerland) with solvent signal as internal reference. ESIMS and HRESIMS were run on a Shimadzu LCMS-IT-TOF mass spectrometer (Shimadzu, Kyoto, Japan) or an Agilent G6230 TOF MS (Agilent Technologies, Palo Alto, USA). Infrared spectra were tested on a Shimadzu IR-450 instrument with $\mathrm{KBr}$ pellets. A JASCO P-1020 digital polarimeter was applied to record optical rotations, using $\mathrm{MeOH}$ as solvent. X-ray diffraction was realized on a Bruker SMART APEX CCD crystallography system.

\section{Plant material}

The flowers of Cimicifuga frigida $(1.0 \mathrm{~kg})$ were collected from Litang County, Sichuan Province, China, in September 2012. Prof. Wang Zongyu, Kunming Institute of Botany, Chinese Academy of Sciences, identified the species. A voucher specimen (KUN no. 201209003) has been deposited at the State Key Laboratory of Phytochemistry and Plant Resources in West China, Kunming Institute of Botany, Chinese Academy of Sciences, PR China.

\section{Extraction and isolation}

$\mathrm{MeOH}$ (4 L, 3 times, 7 days each) was used to extract the dried and milled flowers of Cimicifuga frigida $(1.0 \mathrm{~kg})$ at room temperature. $\mathrm{MeOH}$ was evaporated under vacuum at $50{ }^{\circ} \mathrm{C}$ to afford the extract $(87.4 \mathrm{~g})$. The extract gave fractions A $(10.3 \mathrm{~g}), \mathrm{B}$ $(18.1 \mathrm{~g}), \mathrm{C}(13.4 \mathrm{~g})$, and D (12.3 g) by silica gel CC $(2.5 \mathrm{~kg}, 10 \times$ $150 \mathrm{~cm})$ eluted with $\mathrm{CHCl}_{3}-\mathrm{MeOH}[100: 0(4 \mathrm{~L}), 50: 1(8 \mathrm{~L})$, $10: 1$ (7 L), $0: 100$ (4 L)]. Another six sub-fractions (B.1-B.6) were obtained through RP-18 CC $(500 \mathrm{~g}, 6 \times 50 \mathrm{~cm})$, gradiently eluted with $\mathrm{MeOH}-\mathrm{H}_{2} \mathrm{O}$ from $60: 40$ to $100: 0$. Fraction B.3 (2.7 g) yielded compounds 1 (3.8 mg), 2 (3.2 mg), and 3 (1.9 mg) by silica gel CC $(40 \mathrm{~g}, 3 \times 60 \mathrm{~cm})$ eluting with $\mathrm{CHCl}_{3}-\mathrm{Me}_{2} \mathrm{CO}$ from $30: 1$ gradient to $10: 1$ and semipreparative HPLC (eluted with $\mathrm{CH}_{3} \mathrm{CN}-\mathrm{H}_{2} \mathrm{O}$, gradient from $65: 35$ to $\left.85: 15\right)$. Sub-fractions (C.1-C.4) were obtained by RP-18 CC (eluted with $\mathrm{MeOH}-\mathrm{H}_{2} \mathrm{O}$, gradient from $50: 40$ to $85: 15)$ on fraction C. Consequently, 5 (3.3 $\mathrm{mg})$, and $7(2.8 \mathrm{mg})$ were purified from fraction C.2 $(1.8 \mathrm{~g})$ by silica gel $\mathrm{CC}(40 \mathrm{~g}, 3 \times 40 \mathrm{~cm})$ eluted with $\mathrm{CHCl}_{3}-\mathrm{Me}_{2} \mathrm{CO}$ (gradient from 20:1 to 10:1), and then repeated semipreparative HPLC (eluted with $\mathrm{CH}_{3} \mathrm{CN}-\mathrm{H}_{2} \mathrm{O}$, gradient from $50: 50$ to $65: 35)$. Fraction C. 3 gave compounds $4(2.5 \mathrm{mg})$ and $6(2.7 \mathrm{mg})$ by successively silica gel CC $(40 \mathrm{~g}, 3 \times 40 \mathrm{~cm}$, eluted with $\mathrm{CHCl}_{3}-\mathrm{Me}_{2} \mathrm{CO} 10: 1,13 \mathrm{~L}$ ), and semipreparative HPLC (eluted with $\mathrm{CH}_{3} \mathrm{CN}-\mathrm{H}_{2} \mathrm{O}$, gradient from $50: 50$ to $65: 35$ ).

$(3 \beta, 16 S, 23 R, 24 S)$-16,23-epoxy-3-hydroxy-15-oximido-24-acetoxy25-methoxy-9,19-cycloartane (1). Colorless crystals; $[\alpha]_{\mathrm{D}}^{25}=+38.9$ (c0.09, MeOH); mp 315-317 ${ }^{\circ} \mathrm{C}$; IR (KBr): $\nu_{\max } 3438,2967,2867$, 1740, 1628, 1456, 1374, 1241, 1068, $926 \mathrm{~cm}^{-1}$; see Tables 1 and 2 for ${ }^{1} \mathrm{H}$ NMR (500 MHz, $\mathrm{C}_{5} \mathrm{D}_{5} \mathrm{~N}$ ) and ${ }^{13} \mathrm{C}$ NMR (150 MHz, $\mathrm{C}_{5} \mathrm{D}_{5} \mathrm{~N}$ ) data; positive ESIMS $[\mathrm{M}+\mathrm{Na}]^{+} \mathrm{m} / z$ 582; positive HREIMS $[\mathrm{M}]^{+} \mathrm{m} / \mathrm{z}$ 559.3864 (calcd for $\mathrm{C}_{33} \mathrm{H}_{53} \mathrm{NO}_{6}, 559.3873$ ).

$(3 \beta, 16 S, 23 R, 24 S)-16,23-e p o x y-3,25$-dihydroxy-15-oximido-24acetoxy-9,19-cycloartane (2). White powder; $[\alpha]_{\mathrm{D}}^{25}=-2.1(c 0.03$, $\mathrm{MeOH}$ ); IR (KBr): $\nu_{\max } 3442,2932,2869,1734,1631,1452,1384$, 1248, 1098, $1028 \mathrm{~cm}^{-1}$; see Tables 1 and 2 for ${ }^{1} \mathrm{H}$ NMR (500 $\left.\mathrm{MHz}, \mathrm{C}_{5} \mathrm{D}_{5} \mathrm{~N}\right)$ and ${ }^{13} \mathrm{C}$ NMR $\left(150 \mathrm{MHz}, \mathrm{C}_{5} \mathrm{D}_{5} \mathrm{~N}\right)$ data; positive ESIMS $[\mathrm{M}+\mathrm{Na}]^{+} m / z 568$; positive HREIMS $[\mathrm{M}]^{+} \mathrm{m} / z 545.3723$ (calcd for $\mathrm{C}_{32} \mathrm{H}_{51} \mathrm{NO}_{6}, 545.3716$ ).

$(3 \beta, 16 S, 23 R, 24 S)$-16,23-epoxy-3,24-dihydroxy-15-oximido-25methoxy-9,19-cycloartane (3). White powder; $[\alpha]_{\mathrm{D}}^{25}=+30.1$ (c0.10, MeOH); IR (KBr): $\nu_{\max } 3397,2928,2865,1724,1632,1459$, 1376, 1144, 1081, $927 \mathrm{~cm}^{-1}$; see Tables 1 and 2 for ${ }^{1} \mathrm{H}$ NMR (500 $\left.\mathrm{MHz}, \mathrm{C}_{5} \mathrm{D}_{5} \mathrm{~N}\right)$ and ${ }^{13} \mathrm{C} \mathrm{NMR}\left(150 \mathrm{MHz}, \mathrm{C}_{5} \mathrm{D}_{5} \mathrm{~N}\right)$ data; positive ESIMS $[\mathrm{M}+\mathrm{Na}]^{+} \mathrm{m} / z$ 540; positive HREIMS $[\mathrm{M}]^{+} \mathrm{m} / z 517.3776$ (calcd for $\mathrm{C}_{31} \mathrm{H}_{51} \mathrm{NO}_{5}, 517.3767$ ).

$(3 \beta, 16 S, 23 R, 24 S)$-16,23-epoxy-15-oximido-24-acetoxy-25-hydroxy9,19-cycloart-3-O- $\alpha$-L-arabinopyranoside (4). White powder; $[\alpha]_{\mathrm{D}}^{25}=$ +38.4 (c0.09, MeOH); IR (KBr): $\nu_{\max } 3423$, 2938, 2870, 1745, 1630, 1459, 1375, 1232, 1085, 1020, $937 \mathrm{~cm}^{-1}$; see Tables 1 and 2 for ${ }^{1} \mathrm{H}$ NMR $\left(500 \mathrm{MHz}, \mathrm{C}_{5} \mathrm{D}_{5} \mathrm{~N}\right)$ and ${ }^{13} \mathrm{C} \mathrm{NMR}(150 \mathrm{MHz}$, $\mathrm{C}_{5} \mathrm{D}_{5} \mathrm{~N}$ ) data; positive ESIMS $\left[\mathrm{M}+\mathrm{Na}+\mathrm{H}_{2} \mathrm{O}\right]^{+} \mathrm{m} / z$ 718; positive HREIMS [M] $]^{+} \mathrm{m} / z 677.4129$ (calcd for $\mathrm{C}_{37} \mathrm{H}_{59} \mathrm{NO}_{10}, 677.4139$ ).

$(3 \beta, 16 S, 23 R, 24 S)$-16,23-epoxy-15-oximido-24-acetoxy-25-

hydroxy-9,19-cycloart-3-O(2'-acetoxy)- $\alpha$-L-arabinopyranoside (5). White powder; $[\alpha]_{\mathrm{D}}^{25}=+28.1(c 0.09, \mathrm{MeOH})$; IR (KBr): $\nu_{\max } 3441$, 2935, 2870, 1744, 1629, 1456, 1374, 1232, 1084, $936 \mathrm{~cm}^{-1}$; see Tables 1 and 2 for ${ }^{1} \mathrm{H}$ NMR $\left(500 \mathrm{MHz}, \mathrm{C}_{5} \mathrm{D}_{5} \mathrm{~N}\right)$ and ${ }^{13} \mathrm{C}$ NMR (150 $\left.\mathrm{MHz}, \mathrm{C}_{5} \mathrm{D}_{5} \mathrm{~N}\right)$ data; positive ESIMS $\left[\mathrm{M}+\mathrm{Na}+\mathrm{H}_{2} \mathrm{O}\right]^{+} \mathrm{m} / z$ 760; positive HREIMS $[\mathrm{M}]^{+} \mathrm{m} / z \mathbf{z} 719.4281$ (calcd for $\mathrm{C}_{39} \mathrm{H}_{63} \mathrm{NO}_{12}$, 719.4245).

$(3 \beta, 16 S, 23 R, 24 S)$-16,23-epoxy-15-oximido-24-hydroxy-25-en9,19-cycloart-3-O- $\alpha$-L-arabinopyranoside (6). White powder; $[\alpha]_{\mathrm{D}}^{25}=+10.2(c 0.06, \mathrm{MeOH}) ; \mathrm{IR}(\mathrm{KBr}): \nu_{\max } 3450,2930,2868$, 1630, 1454, 1378, 1250, 1068, 1010, $973 \mathrm{~cm}^{-1}$; see Tables 1 and 2 for ${ }^{1} \mathrm{H}$ NMR (500 MHz, $\mathrm{C}_{5} \mathrm{D}_{5} \mathrm{~N}$ ) and ${ }^{13} \mathrm{C}$ NMR (150 MHz, $\mathrm{C}_{5} \mathrm{D}_{5} \mathrm{~N}$ ) data; positive ESIMS [M + Na $]^{+} \mathrm{m} / z$ 640; positive HREIMS [M] $]^{+} \mathrm{m} /$ $z 617.3943$ (calcd for $\mathrm{C}_{35} \mathrm{H}_{55} \mathrm{NO}_{8}, 617.3928$ ).

$(3 \beta, 16 S, 23 R, 24 S)$-16,23-epoxy-15-oximido-24-hydroxy-25-en9,19-cycloart-3-O-(2'-acetoxy)- $\alpha$-L-arabinopyranoside (7). White powder; $[\alpha]_{\mathrm{D}}^{25}=+15.0$ (c0.06, MeOH); IR (KBr): $\nu_{\max } 3424,2935$, 2869, 1737, 1628, 1454, 1377, 1249, 1069, 1019, $935 \mathrm{~cm}^{-1}$; see Tables 1 and 2 for ${ }^{1} \mathrm{H}$ NMR (500 MHz, $\left.\mathrm{C}_{5} \mathrm{D}_{5} \mathrm{~N}\right)$ and ${ }^{13} \mathrm{C}$ NMR (150 
$\mathrm{MHz}, \mathrm{C}_{5} \mathrm{D}_{5} \mathrm{~N}$ ) data; positive ESIMS [M $\left.+\mathrm{Na}\right]^{+} \mathrm{m} / z$ 682; positive HREIMS [M] $]^{+} \mathrm{m} / z 659.4053$ (calcd for $\mathrm{C}_{37} \mathrm{H}_{57} \mathrm{NO}_{9}, 659.4033$ ).

\section{X-ray crystal structure analysis}

A Bruker APEX DUO diffractometer equipped with an APEX II $\mathrm{CCD}$ was used to obtain the intensity data at $100 \mathrm{~K}$, using $\mathrm{Cu} \mathrm{Ka}$ radiation. Bruker SAINT was applied for cell refinement and data reduction. The structure was determined by direct methods using SHELXS-97. ${ }^{38}$ Refinements were performed with SHELXL-97, using full-matrix least-squares, with anisotropic displacement parameters for all the non-hydrogen atoms. The $\mathrm{H}$ atoms were placed in calculated positions and refined using a riding model. Molecular graphics were calculated with PLATON.

\section{X-ray crystallography of compound 1}

Colorless crystals of compound 1 (CCDC: $1545247 \dagger$ ) was obtained by methanol extract of Cimicifuga frigida. The X-ray crystallographic data of 1: $\mathrm{C}_{33} \mathrm{H}_{53} \mathrm{NO}_{6}$, monoclinic, pace group

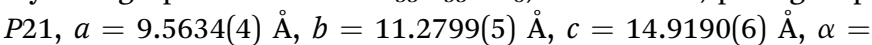
$90.00^{\circ}, \beta=103.4570(10)^{\circ}, \gamma=90.00^{\circ}, V=1565.19(11) \AA^{3}, Z=2$, $D_{\text {calcd }}=1.188 \mathrm{~g} \mathrm{~cm}^{-3}$. The final $R_{1}$ values were $0.1056(I>2 \sigma(I))$. The final $\mathrm{w} R\left(F^{2}\right)$ values were $0.2898(I>2 \sigma(I))$. The goodness of fit on $F^{2}$ was 1.492 . Crystal size, $0.54 \times 0.40 \times 0.10 \mathrm{~mm}^{3}$. Flack parameter $=0.2(3)$. The Hooft parameter is $0.13(8)$ for 1536 Bijvoet pairs.

\section{Hydrolysis and identification of the sugar units in compounds 4-7}

The $\mathrm{MeOH}$ solution $(3 \mathrm{~mL})$ of each compound $(1.5 \mathrm{mg})$ was refluxed with $0.5 \mathrm{~N} \mathrm{HCl}(2 \mathrm{~mL})$ for $2 \mathrm{~h}$. $\mathrm{CHCl}_{3}(3 \times 10 \mathrm{~mL})$ was used to extract the reaction mixture after diluting with $\mathrm{H}_{2} \mathrm{O}$. A monosaccharide was given by neutralizing each aqueous layer with $\mathrm{Ag}_{2} \mathrm{CO}_{3}$ and filtering the precipitate. The monosaccharide from compounds $4-7$ had an $R f\left(\right.$ EtOAc- $\mathrm{CHCl}_{3}-\mathrm{MeOH}-\mathrm{H}_{2} \mathrm{O}$, $3: 2: 2: 1)$ and specific rotation of $[\alpha]_{\mathrm{D}}^{20}+63.4(c 0.06, \mathrm{MeOH})$ corresponding to those of L-arabinose (Sigma-Aldrich).

\section{Cytotoxicity bioassay}

The human tumor cell lines HL-60, SMMC-7721, A549, MCF-7, and SW-480 were used in the cytotoxic assay. These cell lines were obtained from ATCC (Manassas, VA, USA). DMEM medium (Hyclone, USA), supplemented with $10 \%$ fetal bovine serum (Hyclone, USA), was used to culture cells in $5 \% \mathrm{CO}_{2}$ at $37^{\circ} \mathrm{C}$. The MTT (3-(4,5-dimethylthiazol-2-yl)-2,5-diphenyl tetrazolium bromide) method was applied to evaluate the cytotoxicity. ${ }^{39,40}$ Briefly, cells were seeded into each well of a 96-well cell culture plate. After $12 \mathrm{~h}$ of incubation at $37^{\circ} \mathrm{C}$, the test compound was added. Each tumor cell line was exposed to compounds 1, 2, and 3 at concentrations of $3,10,20,50$, and $100 \mu \mathrm{M}$ triplicates for $48 \mathrm{~h}$, to compounds 4 and 6 at concentrations of 1, 3, 10, 30, and $50 \mu \mathrm{M}$ triplicates for $48 \mathrm{~h}$, and to compounds 5 and 7 at concentrations of $0.1,0.3,1,5,10$, and $20 \mu \mathrm{M}$ triplicates for $48 \mathrm{~h}$, respectively. Cisplatin (Sigma, USA) was used as a positive control. After compound treatment, cell viability was detected and a cell growth curve was graphed. $\mathrm{IC}_{50}$ values were calculated by Reed and Muench's method. ${ }^{41}$ (All compounds were dissolved in DMSO as $100 \mathrm{mM}$ stock and 0.1\% DMSO was used as the solvent control).

\section{Acknowledgements}

This project was supported by the National Natural Science Foundation of China (81302670 and U1132604) and the Foundation of State Key Laboratory of Phytochemistry and Plant Resources in West China (P2015-KF03).

\section{Notes and references}

1 E. Liske and P. Wustenberg, Menopause, 1998, 5, 250-255.

2 Y. Nian, H. Zhu, W. R. Tang, Y. Luo, J. Du and M. H. Qiu, J. Nat. Prod., 2013, 76, 896-902.

3 Y. Nian, J. Yang, T. Y. Liu, Y. Luo, J. H. Zhang and M. H. Qiu, Sci. Rep., 2015, 5, 9026-9031.

4 D. J. McKenna, K. Jones, S. Humphrey and K. Hughes, Altern. Ther. Health Med., 2001, 7, 93-100.

5 S. Nobuko, K. Mutsuo, T. Harukuni, M. Teruo, E. Fumio, N. Hoyoku, N. Masahiro, S. Yohiro and H. L. Kuo, Bioorg. Med. Chem., 2005, 13, 1403-1408.

6 Chinese Pharmacopoeia Commission, The Pharmacopoeia of Chinese People's Republic, ed. Y. Li, The Chemical Industry Publishing House, Beijing, China, 2010, vol. 1, pp. 68-69.

7 J. X. Li and Z. Y. Yu, Curr. Med. Chem., 2006, 13, 2927-2951. 8 N. M. Bao, Y. Nian, W. H. Wang, X. L. Liu, Z. T. Ding and M. H. Qiu, Phytochem. Lett., 2015, 12, 200-202.

9 W. H. Wang, Y. Nian, Y. J. He, L. S. Wan, N. M. Bao, G. L. Zhu, F. Wang and M. H. Qiu, Tetrahedron, 2015, 71, 8018-8025.

10 N. M. Bao, Y. Nian, G. L. Zhu, W. H. Wang, L. Zhou and M. H. Qiu, Fitoterapia, 2014, 99, 191-197.

11 Y. Nian, H. Y. Wang, L. Zhou, J. Su, Y. Li and M. H. Qiu, Planta Med., 2013, 79, 60-69.

12 Y. Nian, H. Y. Wang, J. Su, L. Zhou, G. Feng, Y. Li and M. H. Qiu, Tetrahedron, 2012, 68, 6521-6527.

13 Y. Nian, X. M. Zhang, Y. Li, Y. Y. Wang, J. C. Chen, L. Lu, L. Zhou and M. H. Qiu, Phytochemistry, 2011, 72, 1473-1481.

14 Y. Nian, Y. L. Zhang, J. C. Chen, L. Lu, C. Qing and M. H. Qiu, J. Nat. Prod., 2010, 73, 93-98.

15 Y. Nian, J. C. Chen, L. Lu, X. M. Zhang and M. H. Qiu, Helv. Chim. Acta, 2009, 92, 112-120.

16 L. Lu, J. C. Chen, Y. Li, C. Qing, Y. Y. Wang, Y. Nian and M. H. Qiu, Chem. Pharm. Bull., 2012, 60, 571-577.

17 H. Y. Wang, Y. Nian, C. Y. Ma, Y. B. Song, L. Zhou and M. H. Qiu, Chin. J. Chem., 2012, 30, 1265-1268.

18 D. S. Li, Y. Nian, Y. Sun and M. H. Qiu, Helv. Chim. Acta, 2011, 94, 632-638.

19 L. R. Sun, J. Yan, L. Zhou, Z. R. Li and M. H. Qiu, Molecules, 2011, 16, 5701-5708.

20 L. Lu, J. C. Chen, H. J. Song, Y. Li, Y. Nian and M. H. Qiu, Chem. Pharm. Bull., 2010, 58, 729-733.

21 L. Lu, J. C. Chen, Y. Nian, Y. Sun and M. H. Qiu, Molecules, 2009, 14, 1578-1584. 
22 L. R. Sun, J. Yan, Y. Nian, L. Zhou, H. J. Zhang and M. H. Qiu, Molecules, 2008, 13, 1712-1721.

23 L. R. Sun, C. Qing, Y. L. Zhang, S. Y. Ji, Z. R. Li, S. J. Pei, M. H. Qiu, M. L. Gross and S. X. Qiu, Beilstein J. Org. Chem., 2007, 3, 1-6.

24 L. R. Sun, J. Yan, L. Lu, S. J. Pei, Z. R. Li, L. Zhou, X. M. Zhang and M. H. Qiu, Helv. Chim. Acta, 2007, 90, 1313-1318.

25 Z. Ali, S. L. Khan, R. S. Pawar, D. Ferreira and I. K. Khan, J. Nat. Prod., 2007, 70, 107-110.

26 C. Dan, Y. Zhou, Y. Deng, S. L. Peng, L. S. Ding, M. L. Gross and S. X. Qiu, Org. Lett., 2007, 9, 1813-1816.

27 J. C. Gao, F. Huang, J. C. Zhang, G. Y. Zhu, M. S. Yang and P. G. Xiao, J. Nat. Prod., 2006, 69, 1500-1502.

28 J. X. Li, J. Liu, C. C. He, Z. Y. Yu, Y. Du, S. Kadota and H. Seto, Maturitas, 2007, 58, 59-69.

29 N. Sakurai, J. H. Wu, Y. Sashida, Y. Mimaki, T. Nikaido, K. Koike, H. Itokawa and H. Lee, Bioorg. Med. Chem. Lett., 2004, 14, 1329-1332.

30 M. A. Findeis, F. Schroeder, T. D. McKee, D. Yager, P. C. Fraering, S. P. Creaser, W. F. Austin, J. Clardy, R. Wang, D. Selkoe and C. B. Eckman, ACS Chem. Neurosci., 2012, 3, 941-951.
31 J. H. Lee, T. D. Cuong, S. J. Kwack, J. H. Seok, J. K. Lee, J. Y. Jeong, M. H. Woo, J. S. Choi, H. K. Lee and B. S. Min, Planta Med., 2012, 78, 1391-1394.

32 J. A. Compton, Plantsman, 1992, vol. 14, pp. 99-115.

33 Editorial Committee of Chinese flora, Flora of China, ed. W. C. Wang, China Science Press, Beijing, China, 2004, vol. 27, pp. 93-103.

34 C. Ren, Q. Yuan and Q. E. Yang, Nord. J. Bot., 2012, 30, 585595.

35 Y. Shao, A. Harris, M. F. Wang, H. J. Zhang, G. A. Cordell, M. Bowman and E. Lemmo, J. Nat. Prod., 2000, 63, 905-910.

36 G. Kusano, Y. Murakami, N. Sakurai and T. Takemoto, Yakugaku Zasshi, 1976, 96, 82-85.

37 R. W. W. Hooft, L. H. Straver and A. L. Spek, J. Appl. Crystallogr., 2008, 41, 96-103.

38 G. M. Sheldrick, SHELXL97, University of Göttingen, Germany, 1997.

39 T. Mosmman, Immunol. Methods, 1983, 65, 55-63.

40 M. C. Alley, D. A. Scudiero, A. Monks, M. L. Hursey, M. J. Czerwinski and D. L. Fine, Cancer Res., 1988, 48, 589601.

41 L. J. Reed and H. Muench, Am. J. Hyg., 1938, 27, 493-497. 